\title{
Weed Suppression in Pumpkin by Mulches Composed of Organic Municipal Waste Materials
}

\author{
Caitlin E. Splawski, Emilie E. Regnier, S. Kent Harrison², \\ Mark A. Bennett ${ }^{1}$, and James D. Metzger \\ Department of Horticulture and Crop Science, 2021 Coffey Road, Columbus, \\ $\mathrm{OH} 43210$
}

Additional index words. Amaranthus retroflexus, Chenopodium album, Cucurbita pepo, urban agriculture, weed management

\begin{abstract}
Field studies were conducted in 2011 and 2012 to compare mulch treatments of shredded newspaper, a combination of shredded newspaper plus turfgrass clippings (NP + grass), hardwood bark chips, black polyethylene plastic, and bare soil on weeds, insects, soil moisture, and soil temperature in pumpkins. Newspaper mulch or black plastic reduced total weed biomass $\geq 90 \%$, and woodchip or NP + grass mulch each reduced total weed biomass $\mathbf{7 8 \%}$ compared with bare soil under high rainfall conditions in 2011. In 2012, under low rainfall, all mulches reduced weed biomass $97 \%$ or more compared with bare soil. In both years, all mulches resulted in higher squash bug infestations than bare soil. The woodchip, newspaper, and NP + grass mulches retained higher soil moistures than bare soil or black plastic over the course of each growing season, and the woodchip and NP + grass mulches caused greatest fluctuations in soil temperature. Pumpkin yields were abnormally low in 2011 and did not differ among treatments. In 2012, all mulches produced greater total marketable pumpkin fruit weights compared with bare soil, but only black plastic, newspaper, and NP + grass mulches resulted in greater total numbers of marketable pumpkins. Overall results indicate that shredded newspaper or NP + grass mulches may be useful for organic and/or small-scale urban crop producers as sustainable alternatives to black plastic mulch; however, their weed suppression efficacy may require higher application rates with increasing moisture conditions, and they may require greater squash bug control measures than under bare soil conditions.
\end{abstract}

The growing interest in sustainable local food production has created incentives for crop producers, especially in urban areas, to grow food for local consumption using low-cost, renewable materials and/or organic production techniques (Butler and Maronek, 2002; Lorenz and Lal, 2009; McCullum et al., 2005; Organic Trade Association, 2011). Alternative, low-cost weed management strategies are appealing in urban environments because of the close proximity of crop production to people, which may preclude the use of pesticides, or the use of mechanical tillage because of a lack of space or financial resources for equipment and

Received for publication 28 Dec. 2015. Accepted for publication 19 Apr. 2016.

This project was funded by the USDA North Central Integrated Pest Management (NCIPM) program, Grant no. 2009-34103-19900. Salaries and additional research support were provided by state and federal funds appropriated to the Ohio Agricultural Research and Development Center, Ohio State University journal article HCS15-19.

We thank Kelly Keith at the Newark Advocate for providing newspaper, and Mid Ohio Shredding and Ohio Mobile Shredding for their assistance. We also thank Brett Tanner, Weston Applefeller, and the Columbus Crew professional soccer organization for providing grass clippings.

${ }^{1}$ Deceased.

${ }^{2}$ Corresponding author. E-mail: harrison.9@osu. edu. skilled labor. The recycling of urban wastes such as paper and plant trimmings for weed suppression in urban farms could potentially represent an inexpensive and renewable alternative to herbicides, tillage, and hand weeding.

Beginning with their commercial introduction in the 1960s, plastic film mulches coupled with drip irrigation have played a major role in increasing yields of several vegetable crops (Kasirajan and Ngouajio, 2012). Black polyethylene plastic conserves soil moisture and is impervious to light and rainfall, making it effective at controlling weeds but conducive to excessive water runoff (Feeser et al., 2014). Polyethylene mulch in tomato plots resulted in two to four times more water runoff and six to 19 times more pesticide runoff than plots mulched with hairy vetch (Vicia villosa) residues (Rice et al., 2001). Black plastic mulch can also cause heat stress in some crops during hot weather (Gruda, 2008). Another major disadvantage of using nonbiodegradable polyethylene plastic mulches is that they require annual removal and proper disposal (Díaz-Pérez and Batal, 2002). Using black plastic mulch costs U.S. vegetable growers up to $\$ 750 /$ ha every year, which generates $112-135 \mathrm{~kg} \cdot \mathrm{ha}^{-1}$ waste plastic with an added disposal cost of $\approx \$ 50 /$ ha (Feeser et al., 2014).

Various biodegradable materials, including starch or cellulose-based bioplastic films and biofabrics, have been tested as alternatives to plastic mulch with varying results depending on crop, mulch material, and environmental factors (Kasirajan and Ngouajio, 2012; Miles et al., 2012; Wortman et al., 2015). Newspaper mulch is an alternative to nonbiodegradable plastic, but it can be prone to fragmentation on the soil surface and degrade too rapidly to provide a sufficient period of weed suppression (Schonbeck, 1999; Shogren, 2000). Several researchers have investigated that paper treated or mixed with various substances intended to delay biodegradation and/or enhance weed suppression, but results have been variable (Anderson et al., 1995; Shogren, 2000; Shogren and David, 2006).

An important factor affecting the efficacy of newspaper-based mulches for weed suppression is the fragment size of the paper when applied (e.g., shredded vs. sheets), and several studies have demonstrated that shredded newspaper mulches suppressed weeds and resulted in crop yields comparable to those provided by black plastic mulch (Grassbaugh et al., 2004; Laurie et al., 2014; Pellet and Heleba, 1995) or a handweeded control with no mulch (Sanchez et al., 2008). In a study where shredded newspaper was applied at a thickness of 10 or $15 \mathrm{~cm}$, weed germination was suppressed for two seasons without any negative effect on two of the three nursery crops studied (Pellett and Heleba, 1995). Shredded newspaper provided comparable weed suppression to black plastic in tomato (Grassbaugh et al., 2004), and increased yields of sweet corn, soybeans, and tomato were achieved using shredded paper mulch compared with straw mulch or bare ground (Munn, 1992). In contrast, ground newspaper mulch (particle size $\approx 0.1 \mathrm{~cm}^{2}$ ) resulted in collard yield lower than or equivalent to bare soil, and collard tissue nitrogen $(\mathrm{N})$ concentration lower than under bare soil, black plastic, or wood chip mulch (Guertal and Edwards, 1996). Chopped newspaper $(5 \times 5 \mathrm{~cm}$ squares applied at a 7.6-cm thickness) controlled weeds in tomato more consistently than $12.7-\mathrm{cm}$ thick shredded newspaper $(1 \mathrm{~cm}$ by 60 to $75 \mathrm{~cm}$ long strips) or 15.2-cm-thick wheat straw mulch, and also provided greater weed suppression than black plastic or plastic landscape fabric (Monks et al., 1997).

Recycled newsprint is a resource available in large quantities, especially in and around urban centers (Paper Industry Association Council, 2007). In the past, there was concern about the environmental impact of some newspaper inks that contained polycyclic aromatic hydrocarbons (PAHs) of environmental and health concern; however, by the mid-1990s, most newspapers switched to soy-based ink that does not contain PAHs (Anderson et al., 1995). Application of newsprint as a mulch is acceptable under organic certification as long as the newsprint is not contaminated with glossy advertising pages or colored inks (USDA, 2008).

One challenge with using paper as a mulch material is soil $\mathrm{N}$ immobilization. Noncomposted, recycled paper products have a high $\mathrm{C}: \mathrm{N}$ ratio $(\approx 500: 1)$ that upon decomposition 
can result in a depletion of plant-available soil N (Edwards, 1997; Glenn et al., 2000; Tahboub and Lindemann, 2007). Combining paper with plant residues having a lower C:N ratio can reduce immobilization of inorganic $\mathrm{N}$ in the soil. In addition to providing supplemental N, plant residues and other organic materials can increase soil organic carbon and improve soil structure and quality (Saroa and Lal, 2003). Plant residues used as mulch materials have included grass clippings, straw of various cereal grains, wood fiber chipped from downed trees, and municipal leaf waste (Duppong et al., 2004). However, biological residues vary widely in $\mathrm{N}$ content and bioavailability. Fresh grass clippings represent a plant residue that can be comparatively high in bioavailable $\mathrm{N}$ and a potential resource in urban environments (Fang et al., 2007).

Plant residue may be less effective than plastic film as mulch for weed control because it often does not maintain a continuous barrier, and some areas of the soil surface can be left exposed due to residue decomposition or displacement by wind or water. Shredded newspaper becomes cohesive after being wetted by rainfall or overhead irrigation, reducing potential gaps between fragments (Grassbaugh et al., 2004). Combining shredded newspaper with plant residues such as grass clippings may offset the loss in weed control caused by gaps between grass fragments while also offsetting the high $\mathrm{C}: \mathrm{N}$ ratio of paper.

The objective of this study was to compare the effects of shredded newspaper, NP + grass, woodchips, black plastic, and bare soil on weeds, insects, soil moisture, and soil temperature in pumpkin production.

\section{Materials and Methods}

Site preparation and management. Field experiments were conducted in 2011 and 2012 on a Crosby silt loam soil (fine, mixed, mesic Aeric Ochraqualfs) at the Ohio State University Waterman Agricultural and Natural Resources Laboratory in Columbus, $\mathrm{OH}$ (lat. $40^{\circ} 00^{\prime} \mathrm{N}$, long. $83^{\circ} 02^{\prime} \mathrm{W}$ ). Each single row plot was $1.2 \mathrm{~m}$ wide by $9.1 \mathrm{~m}$ long with 10 pumpkin plants per plot. Mulch treatments were replicated four times in a randomized complete block design. In 2011, plots were sprayed with glyphosate [commercial formulation of the isopropylamine salt of $\mathrm{N}$-(phosphonomethyl) glycine] at $2.8 \mathrm{~kg} \cdot \mathrm{ha}^{-1}$ with $2 \%(\mathrm{w} / \mathrm{v})$ ammonium sulfate before tillage on 23 May to control canada thistle [Cirsium arvense (L.) Scop.]. Plots were sprayed again on 13 June with glyphosate at $2.4 \mathrm{~kg} \cdot \mathrm{ha}^{-1}$ with $2 \%(\mathrm{w} / \mathrm{v})$ ammonium sulfate to control weeds that had emerged after tilling, but before mulches were applied. In 2012, the experiment was located in an adjacent field with the same soil type and the field was chisel plowed and disked $1 \mathrm{~d}$ before planting.

After the fields had been tilled and the mulch treatments established, untreated pumpkin seeds were directly seeded on 14 June 2011 and 12 June 2012 at a within-row plant spacing of $91 \mathrm{~cm}$. The pumpkin cultivar Cannonball was chosen because of its bushtype growth habit, powdery mildew resistance, long shelf life, and small fruit weight ( 2 to $3 \mathrm{~kg}$ ). An additional row was planted on the east and west ends of the field to minimize outer border effects. When pumpkin seedlings emerged, plots with missing seedlings were reseeded within a week of the initial planting date. Industry standard fertilization practices were used (Marr et al., 2004) and $\approx 3 \mathrm{~cm}$ water was applied by sprinkler irrigation at seeding, then again in July and August when pumpkins began to show symptoms of water stress. The average annual rainfall in Ohio is $\approx 100 \mathrm{~cm}$. The majority of pumpkin growers in the state do not apply supplemental irrigation, and most who can irrigate do so only in response to severe drought (B. Bergefurd, personal communication). Similarly, our aim in irrigating was not only to relieve drought stress, but also to investigate differences in soil moisture retention among mulch treatments following irrigation. We also wanted to determine whether using black plastic without drip irrigation under would allow sufficient water infiltration through openings within and between the plastic for normal pumpkin growth and development in central Ohio.

Mulch treatments were applied just before pumpkin seeding each year and consisted of 0.032-mm-thick black polyethylene plastic sheet (Hummert International, Earth City, MO), woodchips, shredded newspaper, and $\mathrm{NP}+$ grass. A bare soil treatment served as the weedy control. Composted woodchips of mixed hardwood species common in central Ohio were obtained from the Ohio State University grounds maintenance department, and a local publisher (Newark Advocate, Newark, OH) donated the newspaper. Glossy inserts were removed from newspapers and all newspapers were printed with soy-based ink. The newspaper material was shredded into strips $1.6 \mathrm{~cm}$ wide and $\approx 30 \mathrm{~cm}$ long, and baled by a document shredding company. Fresh grass clippings were obtained from the local professional soccer stadium. The clippings consisted of a mixture of kentucky bluegrass (Poa pratensis L.) and perennial ryegrass (Lolium perenne L.) turf that was mowed on a daily basis. For the NP + grass treatment, shredded newspaper was mixed with grass clippings in a 2:1 ratio (by volume) and applied to plots within 1 week after the clippings were obtained.

On the basis of previous research using newspaper as mulches, the woodchip, newspaper, and NP + grass mulches were applied to the soil surface at a thickness of $\approx 5 \mathrm{~cm}$, resulting in application rates of $\approx 150$ $\mathrm{Mg} \cdot \mathrm{ha}^{-1}$ for the woodchips, $55 \mathrm{Mg} \cdot \mathrm{ha}^{-1}$ for the shredded newspaper, and $50 \mathrm{Mg} \cdot \mathrm{ha}^{-1}$ for the NP + grass mulch (Monks et al., 1997; Munn, 1992; Sanchez et al., 2008). In contrast, the 1.2-m-wide, $0.032-\mathrm{mm}$-thick plastic mulch equated to an application rate of 244 $\mathrm{kg} \cdot \mathrm{ha}^{-1}$. The newspaper and NP + grass treatments were mixed in $76-\mathrm{L}$ plastic tubs with holes drilled in the bottom to allow drainage. $\approx 20 \mathrm{~L}$ of water was poured onto the mulch materials and then the materials were mixed by hand until most of the water had drained from the tubs. This process was carried out to create a uniform mixture and promote hydroentanglement, whereas cellulosic fibers become entangled and physically bond to form a continuous, semirigid fabric upon drying (Rawal et al., 2007; Xiang and Kuznetsov, 2008). In a preliminary investigation, we determined that the prewetting and mixing process improved the strength and integrity of the dried mulch. Where pumpkin was seeded in the organic mulches, the mulch material was removed at each plant spacing to leave an exposed circular soil area $\approx 5 \mathrm{~cm}$ in diameter to allow seedling emergence. A propane torch was used to burn 5 -cm-diameter holes in the plastic mulch for pumpkin seeding.

Local standard measures were used to control squash bugs (Anasa tristis De Geer), striped cucumber beetle (Acalymma vittatum F.), and spotted cucumber beetle (Diabrotica undecimpunctata L.). Kairomone lure traps (Trécé, Inc., Adair, OK) were used to attract, trap, and kill cucumber beetles. During the 2012 season only, 14-g row covers (Hummert International, Earth City, MO) were also used for cucumber beetle control. The row covers were kept in place until 1 July, $\approx 1$ week before flowering began. Row covers were also used because of the high populations of cucumber beetle encountered during the 2011 field season. During 2012, after weekly pest presence was assessed, squash bug eggs were scraped from plants and nymphs and adults found were removed by hand.

Soil moisture and temperature. Meteorological data for precipitation and air temperature were collected from a weather station located within $0.5 \mathrm{~km}$ of the study site. On a weekly basis at solar noon, volumetric soil water content for each plot was measured at a depth of $10 \mathrm{~cm}$ in the middle center of each plot equidistant from adjacent pumpkin plants using a portable impedance probe (Theta Probe type ML2x; Delta-T Devices, Ltd., Cambridge, England). To measure treatment effects on soil temperature, sensors and data loggers (Onset HOBO data loggers, Cape Cod, MA) were installed in three of the four replications. Temperature sensors were buried at depths of $23 \mathrm{~cm} \mathrm{(2011)} \mathrm{or} 5 \mathrm{~cm} \mathrm{(2012)}$ below the soil surface. Temperature sampling depth was reduced in 2012 to obtain temperature readings representative of conditions encountered by weed seeds, microorganisms, and roots closer to the surface.

Data loggers recorded hourly soil temperature measurements for the duration of the growing season, 19 July to 16 Sept. 2011, and 14 June to 10 Sept. 2012. Soil temperature fluctuation was calculated by subtracting the daily minimum temperature from the daily maximum temperature. The temperature sensors and the soil moisture probe were inserted beneath the mulch materials so that measurements were taken at the same soil depth for all treatments. Soil growing degree-days (GDDs) were calculated using daily maximum 
temperature and daily minimum temperature, where daily soil GDD $=[$ (daily $\max +$ daily $\min ) / 2]-20{ }^{\circ} \mathrm{C}$ (Bullied et al., 2003). Cumulative soil GDDs were calculated for each treatment by summing daily soil GDD over time.

Weeds and insects. Weed population density and biomass were determined in a $0.5-\mathrm{m}^{2}$ quadrat placed between crop plants at the south end of each plot on 28 July 2011 and on 10 July 2012. Weeds were counted by species, harvested at the soil surface, dried at $55^{\circ} \mathrm{C}$, and weighed. Weed counts and weed biomass at the end of the season were taken similarly, only at the north end of each plot on 2 Sept. 2011 and 12 Sept. 2012. Weekly insect pest presence was recorded beginning with the first sighting of insect pests and occurred from 3 to 31 Aug. 2011, and 17 to 24 July 2012. The presence and abundance of cucumber beetles and squash bug eggs, nymphs, and adults were recorded on the three central plants in each plot.

Pumpkin growth and yield. Multiplying individual plant height and maximum canopy diameter provided an estimate of plant volume used to monitor crop growth. Measurements were taken on 27 July and 2 Sept. 2011 and 12 July 2012. Three plants per plot were sampled at random and the volumes averaged for each plot. Relative leaf chlorophyll content was estimated (Loh et al., 2002) on 17 July and 24 Aug. 2012, using a chlorophyll meter (Minolta SPAD-502 Plus; Spectrum Technologies, Plainfield, IL). Measurements were taken on a young leaf close to the terminal meristem of the plant, a middleaged leaf, and an older leaf near the base of the plant. Values were averaged for statistical analysis.

Pumpkins were hand-harvested from all plants in each plot on 9 Sept. 2011 and 10 Sept. 2012. Total number of pumpkins per plot was counted and total pumpkin weight per plot was recorded using a portable platform field scale. The number of marketable and unmarketable (rotted or damaged) fruits was recorded.

Statistical analyses. Data were subjected to a combined analysis of variance (ANOVA) using the PROC MIXED procedure in SAS (Statistical Analysis System version 9.3 for Windows; SAS Institute, Cary, NC) for a randomized complete block design with block (rep) as a random effect and treatment (mulch) as a fixed effect for both years of the experiment. Data were analyzed separately by year using the same model when the combined ANOVA results indicated a significant treatment by year interaction. Soil temperature and moisture data were subject to repeated measures ANOVA, in which plot within sampling date and blocks were designated as random effects and treatment was designated as a fixed effect. In the repeated measures ANOVA, plot was also designated as the subject on which repeated measures were taken. Unstructured covariance was specified for the repeated measures analysis (Littell et al., 2006). Differences among least squares treatment means were determined using Fisher's protected least significant difference, the default means comparison procedure implemented by the SAS PDIFF option, with a comparisonwise error rate of alpha $=0.05$ (Littell et al., 2002). Non-normal data for weed and insect data were transformed using either a Box-Cox transformation (count data) implemented by the PROC TRANSREG procedure of SAS or a square root transformation (percentage data) before analysis, then means were back-transformed to original units for presentation in the tables.

\section{Results}

Soil moisture and temperature. There was a significant treatment by year interaction for soil moisture, soil temperature, pumpkin yield, and weed response; therefore, the 2011 and 2012 data were analyzed, and are shown separately. Total precipitation in June through August was $30 \mathrm{~cm}$ in 2011 , but only $16 \mathrm{~cm}$ in 2012 , in comparison with the 30-year average of $33 \mathrm{~cm}$ for the same time period. Significant sampling date by treatment interactions for soil moisture occurred in both years (Table $1 ; P<0.001$ ). In 2011, the newspaper mulch treatment maintained higher soil volumetric water content than the bare soil, black plastic, and NP + grass treatments on six of the nine sampling dates. Soil moisture in the woodchips treatment was statistically similar to moisture in the newspaper mulch on seven sampling dates. Averaged over all sampling dates in 2011, significant main effects indicated the following order of soil volumetric water content: newspaper $(25.0 \%)>$ woodchips $(21.3 \%)>\mathrm{NP}+$ grass $(17.2 \%)=$ bare soil $(16.8 \%)>$ plastic $(12.0 \%)$.

In the comparatively dry season of 2012 , the newspaper, woodchips, and NP + grass treatments maintained higher soil volumetric water content than the bare soil and plastic treatments on eight of the 12 sampling dates (Table 1). Differences in soil moisture among the three organic mulch treatments were not consistent over the growing season. Averaged over all sampling dates in 2012, significant main effects indicated the following order of soil volumetric water content: newspaper $(18.2 \%)=$ $\mathrm{NP}+\operatorname{grass}(18.0 \%)=$ woodchips $(17.5 \%)>$ bare soil $(12.7 \%)>$ plastic $(8.1 \%)$.

In 2011 (wet year), at the 23-cm depth, all mulches maintained a higher average soil temperature than bare soil, and average temperature in the black plastic treatment was slightly higher than the NP + grass mulch, but did not differ from newspaper or woodchips (Table 2). In 2012 (dry year), at the 5-cm soil depth, average soil temperatures under the black plastic, woodchips, and NP + grass mulches did not differ from one another and were greater than under the newspaper or bare soil. The greatest soil temperature fluctuation in 2011 occurred in the woodchip mulch treatment, and fluctuation in the NP + grass treatment did not differ from black plastic. In 2012, temperature fluctuations in the woodchip and NP + grass treatments did not differ, and both fluctuated more than the other treatments (Table 2). In both years, temperature fluctuations in the newspaper mulch did not differ from those in bare soil. Overall temperature fluctuations among treatments were lower, but more variable in 2011 than 2012, reflecting in part the

Table 1. Mulch effects on soil volumetric water content at a 10-cm depth during the summer growing seasons of 2011 and 2012. Pumpkins were seeded on 14 June 2011 and 12 June 2012. Mulch treatments included no mulch (bare soil), black plastic, woodchips, shredded newspaper, and shredded newspaper mixed with grass clippings (NP + grass).

\begin{tabular}{|c|c|c|c|c|c|c|c|c|c|c|c|c|c|}
\hline \multirow{2}{*}{$\frac{\mathrm{Yr}}{2011}$} & Mulch type & \multicolumn{12}{|c|}{ Soil volumetric water content $(\%)^{2}$} \\
\hline & Bare soil & $14.1 \mathrm{c}$ & $17.9 \mathrm{~b}$ & $14.9 \mathrm{~b}$ & $21.7 \mathrm{c}$ & $10.4 \mathrm{c}$ & $14.7 \mathrm{a}$ & $8.8 \mathrm{ab}$ & $24.2 \mathrm{~b}$ & $24.5 \mathrm{ab}$ & & & \\
\hline & Newspaper & $23.4 \mathrm{ab}$ & $25.8 \mathrm{a}$ & $29.6 \mathrm{a}$ & $34.1 \mathrm{a}$ & $20.8 \mathrm{a}$ & $18.0 \mathrm{a}$ & $14.1 \mathrm{a}$ & $31.0 \mathrm{a}$ & $28.0 \mathrm{a}$ & & & \\
\hline & $\mathrm{NP}+$ grass & $17.6 \mathrm{bc}$ & $19.2 \mathrm{~b}$ & $15.6 \mathrm{~b}$ & $24.0 \mathrm{bc}$ & $14.7 \mathrm{bc}$ & $13.3 \mathrm{a}$ & $7.3 \mathrm{~b}$ & $22.1 \mathrm{~b}$ & $20.7 \mathrm{~b}$ & & & \\
\hline & & 21 June & 28 June & 5 July & 12 July & 17 July & 23 July & 2 Aug. & 11 Aug. & 16 Aug. & 29 Aug. & 5 Sept. & 14 Sept. \\
\hline & Woodchips & $23.5 \mathrm{a}$ & $18.3 \mathrm{a}$ & $25.6 \mathrm{a}$ & $15.2 \mathrm{~b}$ & $11.7 \mathrm{a}$ & $21.7 \mathrm{ab}$ & $16.4 \mathrm{~b}$ & $17.7 \mathrm{~b}$ & $15.2 \mathrm{ab}$ & $11.3 \mathrm{ab}$ & $15.2 \mathrm{a}$ & $18.4 \mathrm{a}$ \\
\hline & Newspaper & $18.9 \mathrm{~b}$ & $16.8 \mathrm{a}$ & $21.8 \mathrm{~b}$ & $17.7 \mathrm{ab}$ & $12.2 \mathrm{a}$ & $22.9 \mathrm{a}$ & $21.0 \mathrm{a}$ & $15.3 \mathrm{~b}$ & $18.9 \mathrm{a}$ & $14.0 \mathrm{a}$ & $17.5 \mathrm{a}$ & $21.2 \mathrm{a}$ \\
\hline & $\mathrm{NP}+$ grass & $22.8 \mathrm{a}$ & $17.8 \mathrm{a}$ & $26.5 \mathrm{a}$ & $19.9 \mathrm{a}$ & $14.4 \mathrm{a}$ & $18.5 \mathrm{bc}$ & $13.7 \mathrm{bc}$ & $23.5 \mathrm{a}$ & $17.4 \mathrm{a}$ & $9.8 \mathrm{bc}$ & $16.6 \mathrm{a}$ & $14.6 \mathrm{~b}$ \\
\hline
\end{tabular}

${ }^{\mathrm{z}}$ Least squares means within a year, and column that are followed by the same lower case letter are not significantly different according to Fisher's protected least significant difference with a comparisonwise error rate of alpha $=0.05$. 
differences in measurement depth and soil moisture between years.

Cumulative soil GDDs were calculated for 2012, but not for 2011 due to equipment problems and missing data. In 2012, there were no differences in soil GDD accumulation among treatments at 4 weeks after planting (WAP) (Table 3). However, at 8 and 14 WAP, the order of cumulative soil GDD for mulch treatments was: NP + grass $>$ woodchips $>$ bare soil $>$ plastic $=$ newspaper

Weeds and insects. The most abundant and uniformly distributed weed was common lambsquarters (Chenopodium album) in 2011, and redroot pigweed (Amaranthus retroflexus) in 2012. Other weed species of secondary abundance included yellow foxtail (Setaria pumila), large crabgrass (Digitaria sanguinalis), and common purslane (Portulaca oleracea). In 2011, common lambsquarters accounted for $18 \%$ of total weed biomass in the bare soil control at 6 WAP. All mulches reduced common lambsquarters population density $98 \%$ to $100 \%$ at 6 WAP compared with bare soil, and similar levels of weed suppression were maintained at 12 WAP (Table 4). Total weed suppression by the mulch treatments at $6 \mathrm{WAP}$ was ranked as follows: plastic $>$ woodchips $=$ newspaper $>$ $\mathrm{NP}+$ grass. Suppression of the total weed population density by newspaper was not different from plastic at $12 \mathrm{WAP}$, and the woodchip, newspaper, and NP + grass mulches did not differ in suppressing weed population density at 12 WAP, with suppression ranging from to $78 \%$ to $90 \%$ compared with bare soil. Some weeds had emerged through the transplanting holes in the black plastic by 12 WAP in 2011 (Table 4).

In 2012, weed pressure was considerably lower than in 2011, likely due to drier weather (Table 5). Redroot pigweed was the most abundant weed in 2012, and comprised $18 \%$ of the total weed biomass in the bare soil treatment averaged across both weed harvest dates. All mulches reduced redroot pigweed population density and biomass compared with bare soil at 4 and 14 WAP. All mulches reduced weed population density $\geq 95 \%$ compared with the bare ground control, with only a few escapes in the woodchip mulch at 4 WAP, resulting in slightly less weed suppression than the plastic, newspaper, and NP + grass mulches. At $14 \mathrm{WAP}$, the plastic, woodchip, newspaper, and NP + grass mulches did not differ and suppressed redroot pigweed and total weed biomass $>99 \%$ compared with the bare ground control (Table 5).

The bare soil treatment had lower total numbers of squash bugs than all other treatments except woodchips in 2011 (Table 6). In 2012, the bare soil had the lowest and NP + grass had the highest numbers of squash bugs. In 2011 and 2012, there was no consistent mulch treatment effect on striped cucumber beetle infestation. The plastic mulch treatment harbored more striped cucumber beetles than NP + grass, woodchip, and bare plots in $2011(P<0.05)$, but there were no differences among treatments in 2012.

Table 2. Mulch effects on soil temperature in pumpkin plots at a 23-cm depth in 2011 and 5-cm depth in 2012. Mulch treatments included no mulch (bare soil), black plastic, woodchips, shredded newspaper, and shredded newspaper mixed with grass clippings (NP + grass).

\begin{tabular}{|c|c|c|c|}
\hline$\overline{\mathrm{Yr}}$ & Mulch type & Avg soil temp $\left({ }^{\circ} \mathrm{C}\right)^{z}$ & Avg soil temp fluctuation $\left({ }^{\circ} \mathrm{C}\right)^{y}$ \\
\hline \multirow[t]{5}{*}{$2011(23 \mathrm{~cm})$} & Bare soil & $23.5 \mathrm{c}$ & $12.6 \mathrm{~d}$ \\
\hline & Plastic & $23.9 \mathrm{a}$ & $13.0 \mathrm{bc}$ \\
\hline & Woodchips & $23.8 \mathrm{ab}$ & $13.8 \mathrm{a}$ \\
\hline & Newspaper & $23.8 \mathrm{ab}$ & $12.8 \mathrm{~cd}$ \\
\hline & $\mathrm{NP}+$ grass & $23.7 \mathrm{~b}$ & $13.2 \mathrm{~b}$ \\
\hline \multirow[t]{5}{*}{$2012(5 \mathrm{~cm})$} & Bare soil & $23.7 \mathrm{~b}$ & $14.1 \mathrm{~b}$ \\
\hline & Plastic & $28.8 \mathrm{a}$ & $14.0 \mathrm{~b}$ \\
\hline & Woodchips & $26.9 \mathrm{a}$ & $14.5 \mathrm{a}$ \\
\hline & Newspaper & $23.7 \mathrm{~b}$ & $14.2 \mathrm{~b}$ \\
\hline & $\mathrm{NP}+$ grass & $28.8 \mathrm{a}$ & $14.7 \mathrm{a}$ \\
\hline
\end{tabular}

${ }^{\mathrm{z}}$ Least squares means within a year and column that are followed by the same lower case letter are not significantly different according to Fisher's protected least significant difference with a comparisonwise error rate of alpha $=0.05$.

${ }^{y}$ Soil temperature fluctuation is the average difference between daily maximum and minimum soil temperatures.

Pumpkin growth and yield. In 2011, pumpkin yields were low and variable due in part to low numbers of marketable fruits caused by a combination of high insect pressure and wet weather at the end of the 2011 season, which caused many pumpkins to rot before harvest. As a result, mean yields ranged from only 16 to $322 \mathrm{~kg} \cdot \mathrm{ha}^{-1}$, and there were no differences among treatments in number or total weight of pumpkins (Table 7). Although fruit yields were unaffected by mulches, pumpkin plant size (volume) was greater in the NP + grass treatment in 2011 compared with the other mulch treatments. In 2012, plots with plastic, newspaper, or NP + grass produced a greater number and weight of total and marketable pumpkin fruit than the bare soil treatment. There were no significant differences in pumpkin plant size among mulch treatments in 2012. Plants in the woodchip, newspaper, and NP + grass treatments had higher apparent chlorophyll content than bare soil, suggesting greater $\mathrm{N}$ uptake.

\section{Discussion}

Weed suppression by mulches differed between years, and in general, all of the mulches tested provided significant reductions in weed biomass compared with bare soil during the first 4 to 6 WAP. In 2011, black plastic mulch controlled $100 \%$ of all weeds at 6 WAP, compared with a $97 \%$ and $74 \%$ reduction in the total weed biomass by newspaper and NP + grass, respectively. High soil moisture and warm conditions resulted in greater overall weed emergence and growth in 2011 than 2012, and appeared to cause more rapid degradation of the organic mulch materials. Mulch degradation resulted in areas of exposed soil, and may have released some mineralized $\mathrm{N}$, both of which can contribute to enhanced weed emergence and growth (Gallagher and Cardina, 1998). Other studies indicate that organic particulate mulches tend to be most effective at controlling small-seeded annual weed species such as redroot pigweed and common lambsquarters, but complete soil coverage must be maintained to prevent
Table 3. Mulch effects on cumulative soil growing degree-days (GDD) at various weeks after planting (WAP) pumpkin in 2012. Mulch treatments included no mulch (bare soil), black plastic, woodchips, shredded newspaper, and shredded newspaper mixed with grass clippings (NP + grass).

\begin{tabular}{lccc}
\hline & \multicolumn{3}{c}{ Soil GDD } \\
\cline { 2 - 4 } Mulch type & $4 \mathrm{WAP}^{\mathrm{z}}$ & $8 \mathrm{WAP}$ & $14 \mathrm{WAP}$ \\
\hline Bare soil & $136 \mathrm{a}$ & $266 \mathrm{c}$ & $353 \mathrm{c}$ \\
Plastic & $132 \mathrm{a}$ & $262 \mathrm{~d}$ & $348 \mathrm{~d}$ \\
Woodchips & $137 \mathrm{a}$ & $272 \mathrm{~b}$ & $363 \mathrm{~b}$ \\
Newspaper & $132 \mathrm{a}$ & $264 \mathrm{~d}$ & $351 \mathrm{~d}$ \\
NP + grass & $138 \mathrm{a}$ & $283 \mathrm{a}$ & $377 \mathrm{a}$ \\
\hline
\end{tabular}

${ }^{\mathrm{z}}$ Least squares means within a column that are followed by the same lower case letter are not significantly different according to Fisher's protected least significant difference with a comparisonwise error rate of alpha $=0.05$.

germination of light-sensitive seeds (Teasdale and Mohler, 2000). There is also evidence from the current study that mulches causing greater soil moisture retention, higher soil temperature fluctuations, and more rapid soil GDD accumulation were more conducive to weed establishment than the other treatments.

All mulches provided greater weed suppression in 2012 than in 2011, with plastic and NP + grass mulches maintaining 100\% control and newspaper maintaining greater than $99 \%$ control of the total weed biomass at 4 to $6 \mathrm{WAP}$, a critical period for weed control to reduce crop yield losses from weed competition. Overall, the data presented here indicate that shredded newspaper and NP + grass mulches provided weed suppression comparable with that of black plastic under dry conditions in 2012; however, both were not as effective during higher moisture in 2011 and may, therefore, require higher application rates under normal rainfall conditions in Ohio. It is also important to note for both conventional and organic growers that mulch effects on weed control in our experiment were obtained by starting the experiments with a weed-free seedbed, so preplant weed control is important for effective weed management with mulches. In addition, results generally indicate that all of the mulches 
Table 4. Mulch effects on common lambsquarters (CHEAL) and total weed population density and dry biomass at 6 weeks after planting (WAP) and at harvest 12 WAP in 2011. Mulch treatments included no mulch (bare soil), black plastic, woodchips, shredded newspaper, and shredded newspaper mixed with grass clippings (NP + grass).

\begin{tabular}{|c|c|c|c|c|c|}
\hline \multirow[b]{2}{*}{ Weed } & \multirow[b]{2}{*}{ Mulch type } & \multicolumn{2}{|c|}{$6 \mathrm{WAP}^{\mathrm{z}}$} & \multicolumn{2}{|c|}{12 WAP } \\
\hline & & $\overline{\mathrm{no} .} / \mathrm{m}^{2}$ & $\bar{g} \cdot \mathrm{m}^{-2}$ & $\overline{\mathrm{no} .} / \mathrm{m}^{2}$ & $\mathrm{~g} \cdot \mathrm{m}^{-2 y}$ \\
\hline \multirow[t]{5}{*}{$\overline{\text { CHEAL }}$} & Bare soil & $52.6 \mathrm{a}$ & $21.8 \mathrm{a}$ & $38.9 \mathrm{a}$ & - \\
\hline & Plastic & $0.0 \mathrm{~b}$ & $0.0 \mathrm{~b}$ & $1.0 \mathrm{~b}$ & - \\
\hline & Woodchips & $0.4 \mathrm{~b}$ & $0.3 \mathrm{~b}$ & $0.3 \mathrm{~b}$ & - \\
\hline & Newspaper & $0.0 \mathrm{~b}$ & $0.0 \mathrm{~b}$ & $0.6 \mathrm{~b}$ & - \\
\hline & $\mathrm{NP}+$ grass & $0.3 \mathrm{~b}$ & $0.1 \mathrm{~b}$ & $1.4 \mathrm{~b}$ & - \\
\hline \multirow[t]{5}{*}{ Total } & Bare soil & $207.5 \mathrm{a}$ & $129.7 \mathrm{a}$ & $99.3 \mathrm{a}$ & - \\
\hline & Plastic & $0.0 \mathrm{c}$ & $0.0 \mathrm{c}$ & $0.6 \mathrm{c}$ & - \\
\hline & Woodchips & $17.9 \mathrm{~b}$ & $9.8 \mathrm{~b}$ & $21.8 \mathrm{~b}$ & - \\
\hline & Newspaper & $18.0 \mathrm{~b}$ & $3.4 \mathrm{~b}$ & $9.7 \mathrm{bc}$ & - \\
\hline & $\mathrm{NP}+$ grass & $20.2 \mathrm{~b}$ & $33.6 \mathrm{~b}$ & $21.0 \mathrm{~b}$ & - \\
\hline
\end{tabular}

${ }^{\mathrm{z}}$ Least squares means within a weed type and main effect column that are followed by the same lower case letter are not significantly different according to Fisher's protected least significant difference with a comparisonwise error rate of alpha $=0.05$. Columns lacking letters indicates no significant treatment effect.

${ }^{\mathrm{y}}$ Weed biomass data not collected at 12 WAP in 2011.

Table 5. Mulch effects on redroot pigweed (AMARE) and total weed population density and biomass at 4 weeks after planting (WAP) and at harvest 14 WAP in 2012. Mulch treatments included no mulch (bare soil), black plastic, woodchips, shredded newspaper, and shredded newspaper mixed with grass clippings $(\mathrm{NP}+$ grass $)$.

\begin{tabular}{|c|c|c|c|c|c|}
\hline \multirow[b]{2}{*}{ Weed } & \multirow[b]{2}{*}{ Mulch type } & \multicolumn{2}{|c|}{$4 \mathrm{WAP}^{\mathrm{z}}$} & \multicolumn{2}{|c|}{14 WAP } \\
\hline & & $\overline{\text { no. } / \mathrm{m}^{2}}$ & $\bar{g} \cdot \mathrm{m}^{-2}$ & no. $/ \mathrm{m}^{2}$ & $\mathrm{~g} \cdot \mathrm{m}^{-2}$ \\
\hline \multirow[t]{5}{*}{ AMARE } & Bare soil & $8.0 \mathrm{a}$ & $8.9 \mathrm{a}$ & $8.9 \mathrm{a}$ & $196.4 \mathrm{a}$ \\
\hline & Plastic & $0.0 \mathrm{~b}$ & $0.0 \mathrm{~b}$ & $0.0 \mathrm{~b}$ & $0.0 \mathrm{~b}$ \\
\hline & Woodchips & $0.3 \mathrm{~b}$ & $0.3 \mathrm{~b}$ & $0.3 \mathrm{~b}$ & $1.3 \mathrm{~b}$ \\
\hline & Newspaper & $0.0 \mathrm{~b}$ & $0.0 \mathrm{~b}$ & $0.4 \mathrm{~b}$ & $1.3 \mathrm{~b}$ \\
\hline & $\mathrm{NP}+$ grass & $0.0 \mathrm{~b}$ & $0.0 \mathrm{~b}$ & $0.3 \mathrm{~b}$ & $0.2 \mathrm{~b}$ \\
\hline \multirow[t]{5}{*}{ Total } & Bare soil & $64.8 \mathrm{a}$ & $6.1 \mathrm{a}$ & $44.0 \mathrm{a}$ & $879.8 \mathrm{a}$ \\
\hline & Plastic & $0.0 \mathrm{c}$ & $0.0 \mathrm{c}$ & $0.0 \mathrm{~b}$ & $0.0 \mathrm{~b}$ \\
\hline & Woodchips & $1.5 \mathrm{~b}$ & $1.0 \mathrm{~b}$ & $1.6 \mathrm{~b}$ & $2.3 \mathrm{~b}$ \\
\hline & Newspaper & $0.3 \mathrm{c}$ & $0.1 \mathrm{c}$ & $0.6 \mathrm{~b}$ & $2.0 \mathrm{~b}$ \\
\hline & $\mathrm{NP}+$ grass & $0.0 \mathrm{c}$ & $0.0 \mathrm{c}$ & $2.2 \mathrm{~b}$ & $1.8 \mathrm{~b}$ \\
\hline
\end{tabular}

${ }^{\mathrm{z}}$ Least squares means within a weed type and column that are followed by the same lower case letter are not significantly different according to Fisher's protected least significant difference with a comparisonwise error rate of alpha $=0.05$.

Table 6. Mulch effects on squash bug (Anasa tristis) and striped cucumber beetle (Acalymma vittatum) infestation on pumpkin plants in 2011 and 2012. Mulch treatments included no mulch (bare soil), black plastic, woodchips, shredded newspaper, and shredded newspaper mixed with grass clippings (NP + grass).

\begin{tabular}{llcc}
\hline Yr & Mulch type & Squash bugs $^{\text {zy }}$ (total no.) & Striped cucumber beetles (total no.) $^{2}$ \\
\hline 2011 & Bare soil & $3.5 \mathrm{c}$ & $0.7 \mathrm{~b}$ \\
& Plastic & $5.1 \mathrm{a}$ & $1.9 \mathrm{a}$ \\
& Woodchips & $4.3 \mathrm{bc}$ & $0.7 \mathrm{~b}$ \\
& Newspaper & $4.4 \mathrm{ab}$ & $1.5 \mathrm{ab}$ \\
& NP + grass & $4.6 \mathrm{ab}$ & $0.8 \mathrm{~b}$ \\
2012 & & \\
& Bare soil & $0.1 \mathrm{c}$ & $1.0 \mathrm{a}$ \\
& Plastic & $1.2 \mathrm{~b}$ & $1.3 \mathrm{a}$ \\
& Woodchips & $1.3 \mathrm{~b}$ & $0.8 \mathrm{a}$ \\
& Newspaper & $1.4 \mathrm{~b}$ & $1.1 \mathrm{a}$ \\
& NP + grass & $2.3 \mathrm{a}$ & $0.9 \mathrm{a}$ \\
\hline
\end{tabular}

${ }^{\mathrm{z}}$ Average number of total squash bugs (eggs, nymphs, and eggs) and striped cucumber beetles found on three plants per plot surveyed over a 5- to 6-week period.

${ }^{\mathrm{y}}$ Least squares means within a year and column that are followed by the same lower case letter are not significantly different according to Fisher's protected least significant difference with a comparisonwise error rate of alpha $=0.05$.

harbored greater populations of squash bugs than bare soil and may necessitate additional scouting and the use of insecticides or alternative squash bug control measures.

Newspaper mulch conserved more soil moisture than all other treatments in 2011 (wet year), and the woodchips, newspaper, irrigation in comparison with the other treatments. Previous research indicates that black polyethylene plastic can be $100 \%$ effective in suppressing weeds (Cirujeda et al., 2012), but it can also result in two to four times more water runoff compared with bare soil (Rice et al., 2001). Particulate organic mulches allow water infiltration while providing an evaporation barrier to reduce moisture loss (Teasdale and Mohler, 2000), and addition of organic matter to soil can increase its water holding capacity (Mulumba and Lal, 2008; Saroa and Lal, 2003). Our data indicate that soil volumetric water content was higher with the organic mulches compared with bare soil, indicating that the mulches allowed greater water infiltration and reduced evaporation losses.

Physical characteristics could explain the effectiveness of the newspaper mulch for weed suppression and soil moisture retention. After exposure to wetting and drying, the matrix of long, tangled strips bonds and hardens, similar to the way in which nonwoven fabrics are held together (Xiang and Kuznetsov, 2008). The high tensile strength, high tortuosity, and light color of the newspaper mulch seem to moderate soil temperatures, form an effective evaporation barrier, and preclude weed emergence. In addition, the effect of lower soil temperatures and moist soil conditions beneath shredded newspaper mulch could result in maintenance of seed dormancy in some buried weed seeds while causing lethal germination (nonemergence) in others (Schafer and Chilcote, 1970).

Under high soil moisture conditions and at the 23-cm soil depth in 2011, all mulches resulted in slightly higher average soil temperatures compared with bare soil. A soil's heat capacity (i.e., specific heat) and rate of heat transfer (i.e., thermal conductivity) increases with soil water content, and soil temperature changes occur more slowly with increasing depth (Brady and Weil, 1999). The low thermal conductivity of mulch materials slows heat loss to the atmosphere compared with bare soil (Brady and Weil, 1999), which could explain the slightly higher average soil temperatures the $23-\mathrm{cm}$ depth under mulches in 2011.

Under drier soil conditions and at the $5-\mathrm{cm}$ depth in 2012, newspaper mulch had a lower average soil temperature compared with the other mulch materials and did not differ from bare soil. Mulch effects on soil temperature differ depending on their composition and optical properties, especially color (Ham et al., 1993). Newspaper mulch is light in color and reflects more solar radiation than darker materials, and likely caused soil at the $5-\mathrm{cm}$ depth to remain cooler than the other treatments during the low moisture conditions experienced in 2012. This finding agrees with previous reports of newspaper mulch resulting in lower soil temperatures compared with other mulch materials (Grassbaugh et al., 2004). It is unclear whether the small reductions in soil temperature by newspaper mulch were sufficient to suppress weed germination. 
Table 7. Mulch effects on pumpkin plant volume, total marketable fruit number, and yield in 2011 and 2012 , and average SPAD value depicting leaf tissue chlorophyll content in 2012. Mulch treatments included no mulch (bare soil), black plastic, woodchips, shredded newspaper, and shredded newspaper mixed with grass clippings (NP + grass).

\begin{tabular}{|c|c|c|c|c|c|}
\hline $\mathrm{Yr}$ & Mulch type & Plant volume $\left(\mathrm{m}^{3}\right)^{\mathrm{z}}$ & $\mathrm{SPAD}^{\mathrm{y}}$ & Total marketable fruit (no./plot) & Total marketable fruit wt $\left(\mathrm{kg} \cdot \mathrm{ha}^{-1}\right)$ \\
\hline \multirow[t]{5}{*}{$\overline{2011}$} & Bare soil & $3.5 \mathrm{~b}$ & - & $1.5 \mathrm{a}$ & $47 \mathrm{a}$ \\
\hline & Plastic & $4.6 \mathrm{~b}$ & - & $0.8 \mathrm{a}$ & $16 \mathrm{a}$ \\
\hline & Woodchips & $4.4 \mathrm{~b}$ & - & $4.5 \mathrm{a}$ & $519 a$ \\
\hline & Newspaper & $4.0 \mathrm{~b}$ & - & $2.5 \mathrm{a}$ & $306 a$ \\
\hline & $\mathrm{NP}+$ grass & $6.7 \mathrm{a}$ & - & $3.3 \mathrm{a}$ & $322 \mathrm{a}$ \\
\hline \multirow[t]{5}{*}{2012} & Bare soil & $6.4 \mathrm{a}$ & $43.4 \mathrm{~b}$ & $12.8 \mathrm{c}$ & $19,608 \mathrm{~b}$ \\
\hline & Plastic & $4.8 \mathrm{a}$ & $50.1 \mathrm{ab}$ & $19.5 \mathrm{ab}$ & $33,917 \mathrm{a}$ \\
\hline & Woodchips & $6.6 \mathrm{a}$ & $52.0 \mathrm{a}$ & $16.8 \mathrm{bc}$ & $28,505 \mathrm{ab}$ \\
\hline & Newspaper & $4.5 \mathrm{a}$ & $50.9 \mathrm{a}$ & $21.0 \mathrm{ab}$ & 33,874 a \\
\hline & $\mathrm{NP}+$ grass & $6.1 \mathrm{a}$ & $56.1 \mathrm{a}$ & $21.8 \mathrm{a}$ & $36,232 \mathrm{a}$ \\
\hline
\end{tabular}

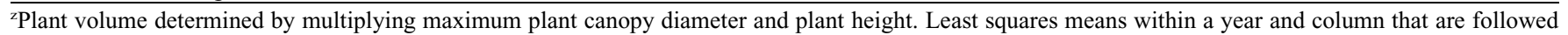

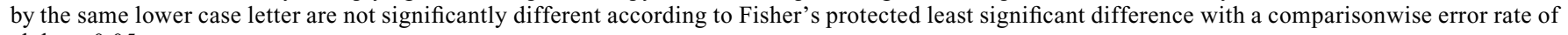
alpha $=0.05$.

${ }^{y}$ SPAD chlorophyll meter readings were not taken in 2011.

In both years, woodchip mulch, and NP + grass mulch in 2012, had the greatest fluctuations in soil temperature, but also resulted in the higher soil GDD accumulation during the 2012 growing season compared with bare soil, black plastic, and newspaper. Soil GDD accumulation at 8 and 14 WAP in 2012, was greatest in NP + grass plots, followed by woodchips. Both results may be attributable to the combined effects of higher moisture content (and thus higher specific heat) and darker color relative to the other treatments. Although the newspaper mulch maintained soil moisture content greater than or equivalent to the woodchip mulch in 2011 and NP + grass mulch in 2012, its lighter color may have been responsible for moderating soil temperature fluctuations and soil GDD accumulation compared with those treatments. Overall average soil temperatures and temperature fluctuations were greater in 2012 than in 2011 due to the shallower measurement depth and drier soil conditions in 2012.

All mulch treatments resulted in higher pumpkin yield than bare soil, but only plastic, newspaper, and NP + grass mulch treatments resulted in significantly higher numbers of marketable fruit. Other researchers have reported that leaf mulches resulted in higher total pumpkin weight and percentages of disease-free, "clean" fruit than bare soil (Wyenandt et al., 2008; 2011). Related studies have reported that residues of rye (Secale cereale), hairy vetch ( $V$. villosa), or oat (Avena sativa) produced equivalent or slightly greater pumpkin numbers and weights, with lower disease incidence than bare soil (Wyenandt et al., 2011). In the current study, the NP + grass mulch resulted in pumpkin plants greater in size and with higher apparent leaf chlorophyll content than plants grown on bare soil, although our study provides no direct proof of greater $\mathrm{N}$ mineralization or uptake in the NP + grass treatment. Previous work showed that leaf mulches supplemented with sidedress $\mathrm{N}$ resulted in greater total and average pumpkin weights than bare soil (Wyenandt et al., 2008).

A challenge with using NP + grass mulch for pumpkin production may be due to increased insect pest and squash bugs. In both years of our study, squash bug numbers were higher in $\mathrm{NP}+$ grass plots than bare soil plots. Previous research on yellow squash (Cucurbita pepo) showed that various mulches, including white plastic, black plastic, and aluminized plastic, harbored greater squash bug populations than bare soil (Cartwright et al., 1990). Cranshaw et al. (2001) found that straw and plastic mulches resulted in increased damage by squash bugs. However, in our study, squash bug presence was not so high in 2012 that it interfered with crop yield in NP + grass plots, which yielded a greater number of both total and marketable fruit. Squash bugs may prefer to live and breed in ground covered by mulch, particularly NP + grass mulch, but the bugs may move about host plants within a field regardless of mulch type. Results generally confirm that additional insect pest control measures may be necessary when using any of the mulch types tested in this study.

Compared with bare soil, the NP + grass mulch had a positive effect on pumpkin growth and yield through increased soil moisture conservation, greater soil GDD accumulation, and increased plant growth and pumpkin yield. Several previous studies have demonstrated improved crop performance using shredded newspaper mulch (Grassbaugh et al., 2004; Pellett and Heleba, 1995; Sanchez et al., 2008). Mulching with grass clippings can also have positive effects on soil nutrient levels and crop performance (Fang et al., 2007); however, the combined effects of newspaper and grass clippings have not been reported previously.

Although the effects of differing newspaper or NP + grass mulch thicknesses on pumpkin production were not tested in this study, our results suggest that the $5-\mathrm{cm}$ thickness was generally sufficient to provide adequate weed control and pumpkin yield. Nonetheless, a thicker mulch layer may be necessary for season-long weed suppression under unusually wet, warm conditions similar to those we experienced in 2011. Our overall results indicate that shredded newspaper and NP + grass mulches may be beneficial for organic and/or small-scale urban crop producers as readily available, inexpensive mulches that offer a more sustainable alternative to black plastic mulch.

\section{Literature Cited}

Anderson, D.F., M. Garisto, J. Bourrut, M.W. Schonbeck, R. Jaye, A. Wurzberger, and R. DeGregorio. 1995. Evaluation of a paper mulch made from recycled materials as an alternative to plastic film mulch for vegetables. J. Sustain. Agr. 7:39-61.

Brady, N.C. and R.R. Weil. 1999. The nature and properties of soils, p. 294-304. 12th ed. Prentice Hall, Saddle River, NJ.

Bullied, W.J., A. Marginet, and R.C. Van Acker. 2003. Conventional- and conservation-tillage systems influence emergence periodicity of annual weed species in canola. Weed Sci. 51:886-897.

Butler, L. and D.M. Maronek (eds.). 2002. Urban and agricultural communities: Opportunities for common ground. Council for Agr. Sci. and Technol., Ames, IA.

Cartwright, B., J.C. Palumbo, and W.S. Fargo. 1990. Influence of crop mulches and row covers on the population dynamics of the squash bug (Heteroptera: Coreidae) on summer squash. J. Econ. Entomol. 83:19881993.

Cirujeda, A., J. Aibar, A. Anzalone, L. MartínClosas, R. Meco, M. Moreno, A. Pardo, A.M. Pelacho, F. Rojo, A. Royo-Esnal, M.L. Suso, and C. Zaragoza. 2012. Biodegradable mulch instead of polyethylene for weed control of processing tomato production. Agron. Sustain. Dev. 32:889-897.

Cranshaw, W., M. Bartolo, and F. Schweissing. 2001. Control of squash bug (Hemiptera: Coreidae) injury: Management manipulations at the base of pumpkin. Southwestern Entomologist 26:147-150.

Díaz-Pérez, J.C. and K.D. Batal. 2002. Colored plastic film mulches affect tomato growth and yield via changes in root-zone temperature. J. Amer. Soc. Hort. Sci. 127:127-136.

Duppong, L.M., K. Delate, M. Liebman, R. Horton, F. Romero, G. Kraus, J. Petrich, and P.K. Chowdbury. 2004. The effect of natural mulches on crop performance, weed suppression and biochemical constituents of catnip and St. John's Wort. Crop Sci. 44:861-869.

Edwards, J.H. 1997. Composition and uses of uncomposted wastepaper and other organics, $\mathrm{p}$. 163-184. In: J.E. Rechigl and H.C. MacKinnon (eds.). Agricultural uses of by-products and wastes. Amer. Chem. Soc., Washington, DC.

Fang, S., B. Xie, and H. Zhang. 2007. Nitrogen dynamics and mineralization in degraded agricultural soil mulched with fresh grass. Plant Soil 300:269-280. 
Feeser, J., G. Zinati, and J. Moyer. 2014. Beyond black plastic: Cover crops and organic no-till for vegetable production. Rodale Inst., Kutztown, PA.

Gallagher, R.S. and J. Cardina. 1998. Phytochromemediated Amaranthus germination II: Development of very low fluence sensitivity. Weed Sci. 46:53-58.

Glenn, J.S., C.H. Gilliam, J.H. Edwards, G.J. Keever, and P.R. Knight. 2000. Recycled waste paper mulch reduces available container N. J. Environ. Hort. 18:188-191.

Grassbaugh, E.M., E.E. Regnier, and M.A. Bennett. 2004. Comparison of organic and inorganic mulches for heirloom tomato production. Acta Hort. 638:171-176.

Gruda, N. 2008. The effect of wood fiber mulch on water retention, soil temperature and growth of vegetable plants. J. Sustain. Agr. 32:629-643.

Guertal, E.A. and J.H. Edwards. 1996. Organic mulch and nitrogen affect spring and fall collard yields. HortScience 31:823-826.

Ham, J.M., G.J. Kluitenberg, and W.J. Lamont. 1993. Optical properties of plastic mulches affect the field temperature regime. J. Amer. Soc. Hort. Sci. 118:188-193.

Kasirajan, S. and M. Ngouajio. 2012. Polyethylene and biodegradable mulches for agricultural applications: A review. Agron. Sustain. Dev. 32:501-529.

Laurie, S.M., N.N. Maja, H.M. Ngobeni, and C.P. Du Plooy. 2014. Effect of different types of mulching and plant spacing on weed control, canopy cover and yield of sweet potato (Ipomoea batatas (L.) Lam). Amer. J. Exp. Agr. 5:450-458.

Littell, R.C., G.A. Milliken, W.W. Stroup, R.D. Wolfinger, and O. Schabenberger. 2006. SAS for mixed models. 2nd ed. SAS Inst., Cary, NC.

Littell, R.C., W.W. Stroup, and R.J. Freund. 2002. SAS for linear models. 4th ed. SAS Inst., Cary, NC.

Loh, F.C.W., J.C. Grabosky, and N.L. Bassuk. 2002. Using the SPAD 502 meter to assess chlorophyll nitrogen content of Benjamin fig and cottonwood leaves. HortTechnology 12:682-686.

Lorenz, K. and R. Lal. 2009. Biogeochemical C and $\mathrm{N}$ cycles in urban soils. Environ. Intl. 35:1-8.

Marr, C., T. Schaplowsky, and T. Carey. 2004. Pumpkins: Commercial vegetable production.
Kansas State Univ. Hort. Rpt. 10 Nov. 2015. $<$ http://www.agmrc.org/media/cms/MF2030_ 0C42997F934A4.pdf>.

McCullum, C., E. Desjardins, V.I. Kraak, P. Ladipo, and H. Costello. 2005. Evidencebased strategies to build community food security. J. Amer. Dietetic Assn. 105:278-283.

Miles, C., R. Wallace, A. Wszelaki, J. Martin, J. Cowan, T. Walters, and D. Inglis. 2012. Deterioration of potentially biodegradable alternatives to black plastic mulch in three tomato production regions. HortScience 47:1270-1277.

Monks, C.D., D.W. Monks, T. Basden, A. Selders, S. Poland, and E. Rayburn. 1997. Soil temperature, soil moisture, weed control, and tomato (Lypersicon esculentum) response to mulching. Weed Technol. 11:561-566.

Mulumba, L.N. and R. Lal. 2008. Mulching effects on selected soil physical properties. Soil Tillage Res. 98:106-111.

Munn, D.A. 1992. Comparisons of shredded newspaper and wheat straw as crop mulches. HortTechnology 2:361-366.

Organic Trade Association. 2011. U.S. organic industry overview. Organic Trade Association 2011 Organic Industry Survey. 17 Sept. 2015. <http://www.ota.com/pics/documents/ 2011 OrganicIndustrySurvey.pdf $>$.

Paper Industry Association Council. 2007. American Forest and Paper Association Community Survey 2007. 5 June 2015. <http://www. paperrecycles.org/news/exec_summ.html $>$.

Pellett, N.E. and D.A. Heleba. 1995. Chopped newspaper for weed control in nursery crops. J. Environ. Hort. 13:77-81.

Rawal, A., D. Moyo, V. Soukupova, and R. Anandjiwala. 2007. Optimization of parameters in hydroentanglement process. J. Ind. Text. 36:207-220.

Rice, P.J., L.L. McConnell, L.P. Heighton, A.M. Sadeghi, A.R. Isensee, J.R. Teasdale, A.A. Abdul-Baki, J.A. Harman-Fetcho, and C.J. Hapeman. 2001. Runoff loss of pesticides and soil: A comparison between vegetative mulch and plastic mulch in vegetable production systems. J. Environ. Qual. 30:1808-1821.

Sanchez, E., W.J. Lamont, Jr., and M.D. Orzolek. 2008. Newspaper mulches for suppressing weeds for organic high-tunnel cucumber production. HortTechnology 18:154-157.
Saroa, G.S. and R. Lal. 2003. Soil restorative effects of mulching on aggregation and carbon sequestration in a Miamian soil in central Ohio. Land Degrad. Dev. 14:481-493.

Schafer, D.E. and D.O. Chilcote. 1970. Factors influencing persistence and depletion in buried seed populations. II. The effects of soil temperature and moisture. Crop Sci. 10:342345 .

Schonbeck, M.W. 1999. Weed suppression and labor costs associated with organic, plastic, and paper mulches in small-scale vegetable production. J. Sustain. Agr. 13:13-33.

Shogren, R.L. 2000. Biodegradable mulches for renewable resources. J. Sustain. Agr. 16:33-47.

Shogren, R.L. and M. David. 2006. Biodegradable paper/polymerized vegetable oil mulches for tomato and pepper production. J. Appl. Hort. 8:12-14.

Tahboub, M.B. and W.C. Lindemann. 2007. Nutrient availability in soil amended with pecan wood chips. HortScience 42:339-343.

Teasdale, J.R. and C.L. Mohler. 2000. The quantitative relationship between weed emergence and physical properties of mulches. Weed Sci. 48:385-392.

USDA (United States Depart. of Agr.). 2008. The national organic program: Program standards. 1 Oct. 2015. <http://www.ams.usda.gov/nop/NOP/ standards.html $>$.

Wortman, S.E., I. Kadoma, and M.D. Crandall. 2015. Assessing the potential for spunbond, nonwoven biodegradable fabric as mulches for tomato and bell pepper crops. Scientia Hort. 193:209-217.

Wyenandt, C.A., J.R. Heckman, and N.L. Maxwell. 2008. Pumpkin fruit size and quality improve with leaf mulch. HortTechnology 18:361-364.

Wyenandt, C.A., R.M. Riedel, L.H. Rhodes, M.A. Bennett, and S.G.P. Nameth. 2011. Fall- and spring-sown cover crop mulches affect yield, fruit cleanliness, and fusarium fruit rot development in pumpkin. HortTechnology 21:343354.

Xiang, P. and A.V. Kuznetsov. 2008. Simulation of shape dynamics of a long flexible fiber in a turbulent flow in the hydroentanglement process. Intl. Commun. Heat Mass Transf. 35:529534. 